\title{
Treating malignant melanoma when a rare BRAF V600M mutation is present: case report and literature review
}

\author{
ANDREI POPESCU ${ }^{1,4}$, ANDREI HAIDAR ${ }^{2}$, RODICA MARICELA ANGHEL ${ }^{3,4}$ \\ ${ }^{1}$ Medical Oncology Department, "Colentina” Clinical Hospital, Bucharest, Romania \\ ${ }^{2}$ Gastroenterology Department, "Colentina" Clinical Hospital, Bucharest, Romania \\ ${ }^{3}$ Department of Radiotherapy II, "Prof. Dr. Alexandru Trestioreanu" Institute of Oncology, Bucharest, Romania \\ 4 "Carol Davila" University of Medicine and Pharmacy, Bucharest, Romania
}

\begin{abstract}
Recent years have brought major advances in the treatment of malignant melanoma. One such an advance is the treatment with BRAF tyrosine-kinase inhibitors in metastatic malignant melanomas that harbor mutations in the BRAF gene. The trials that have been performed in this setting have demonstrated superior response rates and increased overall survival, however, they mostly included patients with melanomas carrying the more common V600E and V600K mutations, not being able to assess the benefit of these treatments in situations where more rare mutations of the BRAF gene are present. We present the evolution of a patient with malignant melanoma with a rare V600M mutation in the BRAF gene, that was eventually treated with vemurafenib. Also we present a brief review of the major phase III trials that showed benefit with tyrosine-kinase inhibitors in BRAF mutated melanoma, with respect to the BRAF mutations included.
\end{abstract} dabrafenib.

Key words: melanoma, cutaneous malignant, melanoma, protein-tyrosine kinases, vemurafenib,

\section{INTRODUCTION}

Malignant melanoma is one of the most aggressive types of cancer, accountable for the great majority of deaths by skin cancer and with a rise in incidence. Although curable in its early stages, advanced/metastatic melanoma carries a very bad prognosis; the efforts to combat metastatic malignant melanoma through systemic therapy have all but stagnated up until relatively recently, with the description of the MAPK pathway as a therapeutic target [1] and the discovery of BRAF inhibition through tyrosine-kinase inhibiting drugs. Mutations in the BRAF gene seem to be present in around $40-50 \%$ of the cutaneous melanomas [2-4] and have been clinically proven to correlate with an increased benefit in terms of response rate and overall survival, compared to classical chemotherapy, from treatment with BRAF-inhibiting drugs, such as vemurafenib or dabrafenib $[5,6]$. The clinical trials, however, support this correlation in cases with V600E and V600K mutations, which are the more prevalent mutations (more than 95\%), and cannot address the issue of benefit (or lack of) with the more rare mutations, such as V600M or V600D. The V600M BRAF mutation is present in less than
$1 \%$ of melanoma cases [4] and it consists of a substitution at position 600 in the BRAF gene, from a valine $(\mathrm{V})$ to a methionine $(\mathrm{M})$. We present the evolution of a metastatic melanoma patient with a BRAF V600M rare mutation, who was treated with vemurafenib.

\section{CASE REPORT}

In November 2014 we received in consultation a 52 years old patient of Syrian nationality, without any significant medical history, that had been recently operated in the Plastic Surgery Department for a skin lesion located on his right hallux; he also underwent a right inguinal dissection, as he had palpable nodes at presentation. The pathologic examination revealed an acral lentiginous melanoma that was invasive at the level of the aponeurosis (Clark level V, Breslow 5mm, with ulceration, vascular invasion and satellite nodules in the nearby dermis) and multiple massive lymphoganglionar metastasis in the groin, with macroscopic invasion in the nearby veins. Computed tomography of chest, abdomen and pelvis, with contrast, showed no signs of distant metastases, and the disease was staged as $\mathrm{pT} 4 \mathrm{~b} \mathrm{pN} 3 \mathrm{M} 0$. 
After discussing the very high risk of disease progression with the patient, he opted for adjuvant treatment with high-dose interferon, as he was in good enough condition (ECOG 1, mild stiffness in the right leg, no other symptoms, normal bloodwork). Radiotherapy to the right inguinal basin was also considered, but was postponed as the groin had not healed properly after surgery. He tolerated the highdose interferon rather well, with moderate fatigue, chills and a moderate elevation of his transaminases.

After 4 months of treatment with interferon, the patient was admitted in the Gastroenterology Department where he underwent an upper-endoscopy which showed multiple metastasis in the gastric mucosa (Figure 1) and an abdominal ultrasound which showed 3 metastases in the right lobe of the liver, up to $1.3 \mathrm{~cm}$ in diameter as well as enlarged adenopathic masses adjacent to the right external iliac vessels, up to $4.7 \mathrm{~cm}$ in diameter. His blood work showed also, for the first time, an increased seric lactic-dehydrogenase, more than twice the upper normal value per laboratory standard.

Seeing that no other treatment was available in Romania at the time, the patient was started on palliative chemotherapy with dacarbazine, $1000 \mathrm{mg} /$ square meter, i.v., every 3 weeks. After only 2 cycles though, the patient was admitted in the Neurosurgery Department, at another hospital, where he was operated for a large right-parasagittal frontal brain tumor, with perilesional edema and mass effect over the ventricular system (Figure 2); there were also multiple similar lesions disseminated in the supratentorial volume. The pathology report diagnosed a melanoma metastasis.

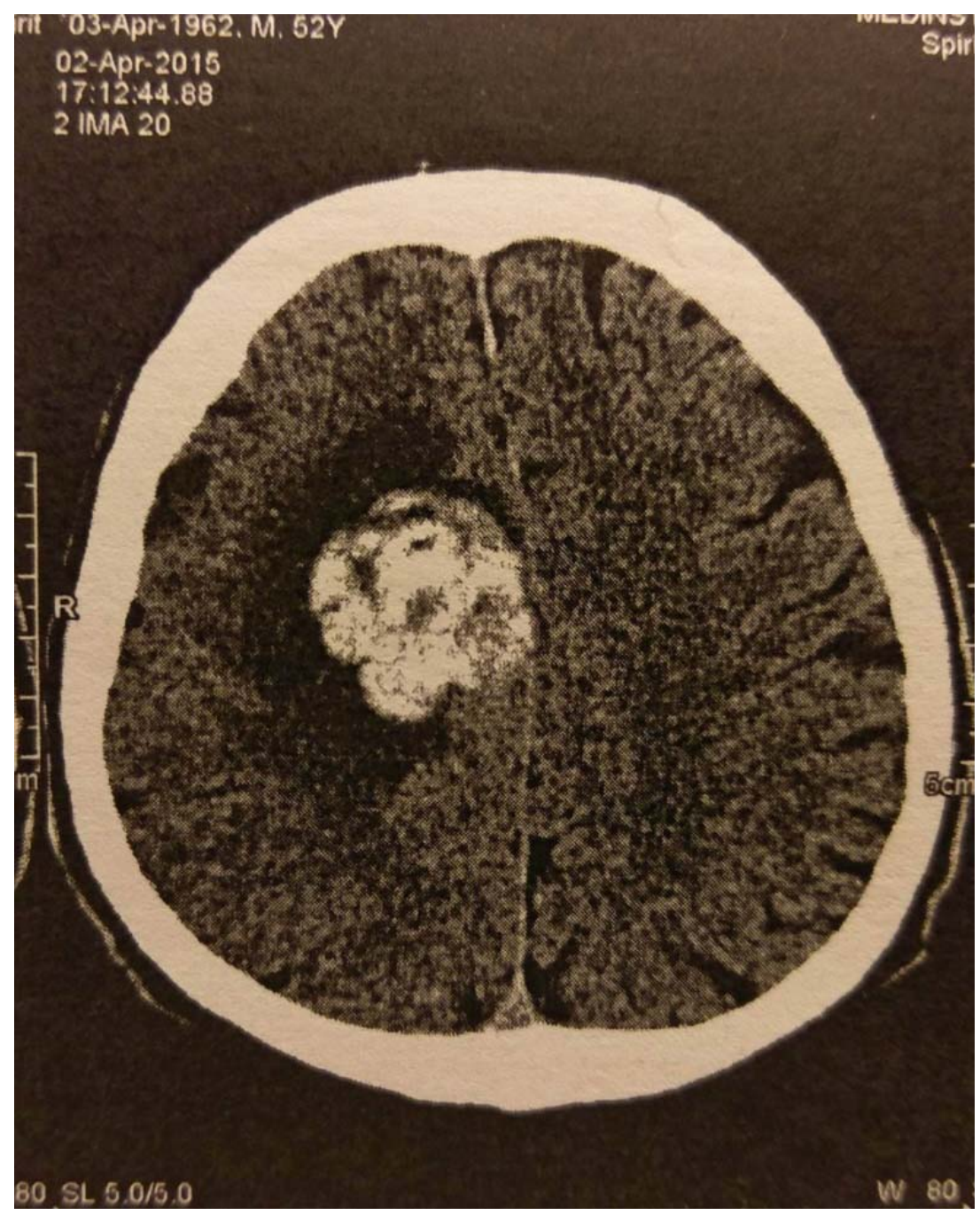

Figure 1: A large right paramedian metastasis. 


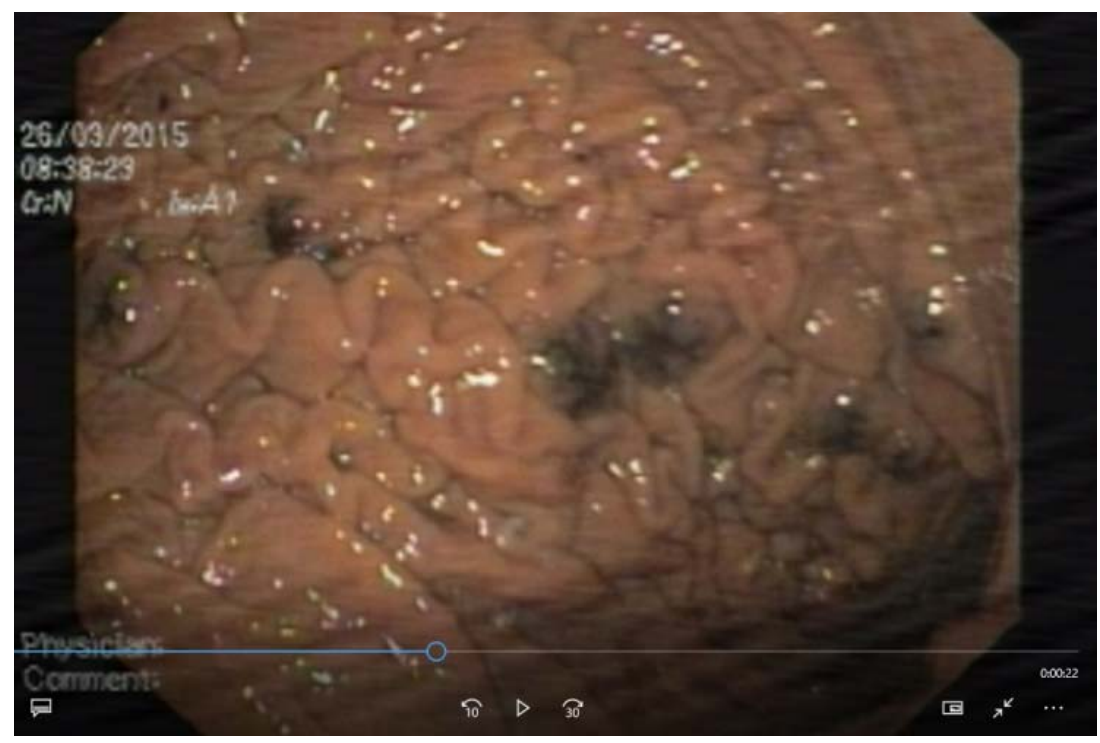

Figure 2: Gastric mucosa metastasis from malignant melanoma.

BRAF testing as well as anti-BRAF treatment had become available at that time in our country, so the initial biopsy specimen was tested by PCR and reverse hybridization; a V600E mutation was not detected, but the test was positive for a V600M mutation (nucleotide substitution c. $1798 \mathrm{G}>\mathrm{A}$ ).

Although the uncommon mutation was detected, seeing as the disease was so rapidly progressing and that there were no viable alternative treatment options, the patient was started on vemurafenib $960 \mathrm{mg} /$ day per os. The new treatment was tolerated well, but unfortunately the patient died after less than 2 months, probably through cerebral progression, as he did not receive whole-brain radiation therapy timely enough.

\section{DISCUSSION}

The general landscape of the treatment of metastatic cutaneous melanoma has suffered major changes in the past few years, partly with the discovery of the new tyrosine-kinase molecules capable of disrupting the intracellular signals that regulate tumor growth within the MAPK pathway. We provide a summary of the major randomized control trials of these new drugs used in the metastatic/advanced setting (Table 1).

Table 1

Summary of phase III trials with BRAF inhibitors

\begin{tabular}{|l|l|c|c|c|c|}
\hline \multicolumn{1}{|c|}{ Trial } & \multicolumn{1}{|c|}{ Agents } & N & PFS (months) & OS (months) & Mutations \\
\hline BRIM-3 & vemurafenib $v s$ dacarbazine & 675 & $6.9 v s 1.6$ & $13.6 v s 9.6$ & $\begin{array}{c}\text { V600E, some non-V600E } \\
(<3 \%), \text { no V600M }\end{array}$ \\
\hline BREAK-3 & dabrafenib $v s$. dacarbazine & 733 & 5.1 vs 2.7 & $18.2 v s 15.6$ & V600E \\
\hline COBRIM & $\begin{array}{l}\text { vemurafenib + cobimetinib } v s \\
\text { vemurafenib }\end{array}$ & 495 & $9.9 v s 6.2$ & not available yet & V600 \\
\hline COMBI-D & dabrafenib + trametinib $v s$ dabrafenib & 423 & $11 v s 8.8$ & $25.1 v s 18.7$ & V600E, V600K \\
\hline COMBI-V & dabrafenib + trametinib $v s$ vemurafenib & 1645 & $11.4 v s 7.3$ & not available yet & V600E, V600K \\
\hline
\end{tabular}

$\mathrm{N}=$ number of patients; $\mathrm{PFS}=$ progression free survival; $\mathrm{OS}=$ overall survival.

The first phase III trial to demonstrate improvement of overall survival by treatment with vemurafenib in patients melanoma harboring a V600E BRAF mutation is BRIM-3. This trial randomized 1:1 a total of 675 patients with advanced BRAF mutated malignant melanoma that had not been previously treated, between vemurafenib $960 \mathrm{mg}$ per os twice a day and dacarbazine $1000 \mathrm{mg} /$ sqm intravenously every three weeks, the standard treatment at the time, as control. After 6 months, overall survival (OS) was increased from $64 \%$ in the dacarbazine arm (95\% CI, $56-73 \%)$ to $84 \%$ in the vemurafenib arm (95\% CI, 78-89\%). Response rates (RR) were also increased: $48 \%$ for vemurafenib and only $5 \%$ for dacarbazine, which was comparable to historical references [5]. A more recent analysis, at a median follow-up of 12.5 months for patients started on vemurafenib (IQR 7.7-16.0) and 9.5 months 
for patients on dacarbazine (IQR 3.1-14.7), after the cross-over of $25 \%$ patients that had been treated with dacarbazine, showed a significant increase in overall survival in the vemurafenib arm compared to dacarbazine, of 13.6 months (95\% CI, 12-15.2) vs. 9.7 months (95\% CI, 7.9-12.8), with a hazard ratio of 0.7 (95\% CI, 0.57-0.87), with a $\mathrm{P}$ value of 0.0008; median progression free survival (PFS) was also increased to 6.9 months $(95 \% \mathrm{CI}, 6.1-7)$ for vemurafenib vs. 1.6 months (95\% CI, 1.6-2.1), $\mathrm{HR}=0.38(95 \% \mathrm{CI}, 0.32-0.46), \mathrm{P}<0.0001$. The benefit was seen in patients with $\mathrm{V} 600 \mathrm{E}$ as well as V600K mutations [6].

BREAK-3 demonstrated benefit with another tyrosine-kinase inhibitor, dabrafenib, over dacarbazine. The trial included 733 patients with V600Emutant stage IV or unresectable stage III melanoma and showed an increase in median PFS from 2.7 months with dacarbazine $(1000 \mathrm{mg} / \mathrm{sqm}$ iv every 3 weeks) to 5.1 with dabrafenib $(150 \mathrm{mg}$ po twice daily), with a HR of 0.3 (95\% CI, 0.18-0.51; $\mathrm{P}<0.0001$ ) [7].

The short-lived response seen with these therapies has led to the strategy of combining BRAF inhibitors with other molecules that inhibit a downward inhibitor in the MAPK pathway called MEK. The clinical trials have been successful.

A multicentric multinational phase III randomized study (COBRIM) has compared the therapeutic effect of combining vemurafenib (BRAF inhibitor) plus cobimetinib (MEK inhibitor) versus that of vemurafenib alone (1:1 randomization), in a population of 495 patients with advanced (unresectable) or metastatic melanoma that had a BRAF mutation present (V600E and V600K; in 38 patients the BRAF mutation was not known). Median PFS was 9.9 months in the group treated with vemurafenib/ cobimetinib and 6.2 months in the group treated with vemurafenib alone, $\mathrm{HR}=0.51(95 \% \mathrm{CI}, 0.39$ $0.68 ; \mathrm{P}<0,001)$. Response rate in the combination arm was $68 \%$ compared to $45 \%$ in the monotherapy group $(\mathrm{P}<0.001)$, including $10 \%$ and $4 \%$ complete response, respectively. An interim analysis also showed an increase in OS at 9 months, from $73 \%$ (95\% CI, $65-80 \%)$ in the monotherapy arm to $81 \%$ (95\% CI, 75-87\%) in the combination [8].

Another randomized trial, the COMBI-D trial, done in medical centers in 14 countries (423 patients distributed 1:1), compared the combination of dabrafenib plus trametinib versus dabrafenib plus placebo, in patients with malignant melanoma stage IV or unresectable stage IIIC, with V600E/K BRAF mutation present. Median OS was 25.1 months (95\% CI, 19.2 - not reached) in the combination treatment arm, as compared to 18.7 months ( $95 \% \mathrm{CI}$, $15.2-23.7 ; \mathrm{P}=0.0107$ ) in the monotherapy arm [9].

Similarly, the COMBI-V trial evaluated the effect of the combination of dabrafenib plus trametinib versus vemurafenib alone in 1645 patients with advanced (unresectable stage IIIC or stage IV) melanoma with BRAF V600E or V600K mutation. After $77 \%$ of events had occurred, the overall survival rate at 12 months was $72 \%$ (95\% CI, 67 to 77 in the combination-therapy group and $65 \%$ (95\% CI, 59 to 70 ) in the vemurafenib group (hazard ratio for death in the combination-therapy group, $0.69 ; 95 \% \mathrm{CI}, 0.53$ to $0.89 ; \mathrm{P}=0.005$ ). Median progression-free survival was 11.4 months in the combination-therapy group and 7.3 months in the vemurafenib group (hazard ratio, $0.56 ; 95 \%$ CI, 0.46 to $0.69 ; \mathrm{P}<0.001)$. The objective response rate was $64 \%$ in the combination-therapy group and $51 \%$ in the vemurafenib group $(\mathrm{P}<0.001)[10]$.

Even though for BRAF V600E/K mutant metastatic melanoma treatment with BRAF inhibitors is standard, with proven high clinical benefit, the evidence to support the same treatment in more rare mutations, such as $V 600 \mathrm{M}$, is lacking. The very little data available consists of mostly case reports and; the cases presented seem to show benefit, unlike in our patient. One such report is of a 54 years old patient who had a radiological response after treatment with the BRAF inhibitor dabrafenib combined with the MEK inhibitor trametinib [11]. Another showed an "overwhelming" response with monotherapy with dabrafenib in a 66 years old patient whose disease was found to harbor, interestingly, a dual V600E and V600M BRAF mutation [12].

\section{CONCLUSION}

Even relatively short, the duration of treatment with vemurafenib is considered by the authors to have been long enough for a response to manifest itself, should there have been any. Further data regarding best management of patients with advanced melanoma that do have BRAF mutations, but the more rare kind, is awaited. Until then we conclude that, if a patient with metastatic malignant melanoma with a rare V600M mutation in the BRAF gene is identified, the standard strategies of either BRAF inhibition alone or BRAF combined with MEK inhibition are potentially useful, the best option is probably enrollment in a clinical trial.

Conflict of interest disclosure: The authors declare that there are not conflicts of interest. 
Tratamentul oncologic al melanomului malign a suferit schimbări majore în ultimii ani. $O$ astfel de schimbare este reprezentată de tratamentul cu inhibitori de tirozin-kinază la pacienții cu boală metastatică şi cu prezența mutației genei $B R A F$. Studiile efectuate au demonstrat o superioritate netă în termeni de rate de răspuns şi de supraviețuire generală; totuşi, aceste studii au inclus aproape exclusiv pacienți ale căror boli aveau mutații de tip V600E şi V600K, neputând să aprecieze beneficiul acestor noi tratamente în cazurile cu mutații rare ale genei BRAF. Prezentăm evoluția unui pacient cu melanom malign cu o mutație rară a genei BRAF, respectiv V600M, ce a fost tratat inclusiv cu vemurafenib. Includem de asemenea o sinteză a studiilor clinice de fază III ce au demonstrat eficiența inhibitorilor de tirozin-kinază în melanom, cu mențiune la tipurile de mutații BRAF incluse.

Correspondence to: Andrei Popescu, MD, Medical Oncology Department,

"Colentina" Clinical Hospital, Bd. Ştefan cel Mare nr. 11-13, Bucharest, Romania

Telephone: 0726.724.105

E-mail: andreipopescu1983@gmail.com

\section{REFERENCES}

1. CHENG Y, ZHANG G, LI G. Targeting MAPK pathway in melanoma therapy. Cancer Metastasis Rev. 2013; 32(3-4):567-84.

2. DAVIES H, BIGNELL GR, COX C, STEPHENS P, EDKINS S, CLEGG S, et al. Mutations of the BRAF gene in human cancer. Nature. 2002; 417(6892):949-54.

3. MALDONADO JL, FRIDLYAND J, PATEL H, JAIN AN, BUSAM K, KAGESHITA T, et al. Determinants of BRAF mutations in primary melanomas. J Natl Cancer Inst. 2003; 95(24):1878-90.

4. VOSKOBOYNIK M, MAR V, MAILER S, et al. Clinico-pathological characteristics associated with BRAF $(K)(601 E)$ and $B R A F(L)$ (597) mutations in melanoma. Pigment Cell Melanoma Res. 2016; 29 (2):222-8.

5. CHAPMAN PB, HAUSCHILD A, ROBERT C, HAANEN JB, ASCIERTO P, LARKIN J, et al. Improved survival with vemurafenib in melanoma with BRAF V600E mutation. N Engl J Med. 2011; 364(26):2507-16.

6. MCARTHUR GA, CHAPMAN PB, ROBERT C, et al. Safety and efficacy of vemurafenib in BRAFV600E and BRAFV600K mutation-positive melanoma (BRIM-3): extended follow-up of a phase 3, randomised, open-label study. The Lancet Oncology. 2014; 15(3):323-332.

7. HAUSCHILD A, GROB JJ, DEMIDOV LV, JOUARY T, GUTZMER R, MILLWARD M, et al. Dabrafenib in BRAF-mutated metastatic melanoma: a multicentre, open-label, phase 3 randomised controlled trial. Lancet. 2012; 380(9839):358-65.

8. LARKIN J, ASCIERTO PA, DRENO B, et al. Combined Vemurafenib and Cobimetinib in BRAF-Mutated Melanoma. N Engl J Med. 2014; 371:1867.

9. LONG GV, STROYAKOVSKIY D, GOGAS H, et al. Dabrafenib and trametinib versus dabrafenib and placebo for Val600 BRAF-mutant melanoma: a multicentre, double-blind, phase 3 randomised controlled trial. Lancet 2015; 386(9992):444-51.

10. ROBERT C, KARASZEWSKA B, SCHACHTER J, et al. Improved Overall Survival in Melanoma with Combined Dabrafenib and Trametinib. N Engl J Med 2015; 372:30-39

11. PARAKH S, MURPHY C, LAU D, CEBON JS, ANDREWS MC. Response to MAPK pathway inhibitors in BRAF V600Mmutated metastatic melanoma. J Clin Pharm Ther. 2015; 40(1):121-3.

12. PONTI G, TOMASI A, PELLACANI G. Overwhelming response to Dabrafenib in a patient with double BRAF mutation (V600E; V600M) metastatic malignant melanoma. J Hematol Oncol. 2012; 5:60.

Received October 15, 2017 